\title{
Comparison of Transarterial Y90 Radioembolization and Conventional Transarterial Chemoembolization in Hepatocarcinoma Patients: A Meta-analysis
}

\author{
NA REN, S. QIN ${ }^{1}$, L. DING ${ }^{2}$, ERNA JIA ${ }^{1}$ AND JINRU XUE* \\ Department of Thoracic Surgery, China-Japan Union Hospital of Jilin University, Changchun, China, ${ }^{1}$ Department of Gastro- \\ enterology, China-Japan Union Hospital of Jilin University, Changchun, China, ${ }^{2}$ Department of Radiology, China-Japan Union \\ Hospital of Jilin University, Changchun, China
}

Ren et al.: Efficacy of Y90-TARE vs. c-TACE in Hepatocarcinoma patients

\begin{abstract}
To compare the efficacy of Yttrium-90 radioembolization and conventional transarterial chemoembolization in the unresectable hepatocellular carcinoma patients, clinical treatment studies on Yttrium-90 radioembolization and conventional transarterial chemoembolization were identified using PubMed. Tumor response, 3 y overall survival rates were analyzed and compared. Seven studies, including 6 case-control studies and one cohort study, published from December 2008 to January 2017, with a total of 1426 patients, were included in this meta-analysis. Subgroup analyses performed by various designs were included in this meta-analysis. An increase in 3 y overall survival rates was observed in Yttrium-90 radioembolization group compared to the conventional transarterial chemoembolization group (overall survival rate $=2.03,95 \% \mathrm{CI}-1.45,2.84, \mathbf{p}<\mathbf{0 . 0 0 0 1})$. In contrast, there was no significant difference in tumor response between Yttrium-90 radioembolization and conventional transarterial chemoembolization groups. However, subgroup analysis indicated higher overall tumor control (overall survival rate $=2.18,95$ $\%$ CI- 1.30, 3.64, $\mathrm{p}=\mathbf{0 . 0 0 3}$ ) in Yttrium-90 radioembolization group. The current meta-analysis suggested that Yttrium-90 radioembolization is associated with significantly higher 3 y overall survival rate. Using the subgroup analysis, the meta-analysis demonstrated higher overall tumor control in the Yttrium-90 radioembolization group.
\end{abstract}

Key words: Y90-TARE, c-TACE, hepatocarcinoma, 3 y overall survival, overall tumor control 
Hepatocellular carcinoma (HCC) has the third most serious cancer mortality worldwide and is a rapidly rising global disease burden with 748300 new cases diagnosed yearly ${ }^{[1]}$. The primary treatment for $\mathrm{HCC}$ is surgical resection. However, HCC is diagnosed at intermediate or advanced stages in approximately $70 \%$ of cases in which the tumor can't be resected ${ }^{[2]}$. In recent years, regional therapies, such as ablation, conventional transarterial chemoembolization (c-TACE), radioembolization with Yttrium-90 microspheres (Y90TARE), have emerged as tools of palliation, surgical down staging and bridging therapy prior to transplant. c-TACE has been recommended as the standard therapy for intermediate stage $\mathrm{HCC}^{[3]}$. Y90-TARE has been regarded as an alternative therapy to c-TACE for unresected $\mathrm{HCC}^{[4]}$. The American Association for the Study of Liver Diseases (AASLD) has recommended c-TACE for intermediate stage or Barcelona clinic liver cancer (BCLC)-B stage of unresectable HCC ${ }^{[5,6]}$. Y90TARE has been advocated as the preferred therapy for HCC with portal vein thrombosis because of lower risk of hepatic parenchymal damage and ischemia ${ }^{[7]}$. However, the overall survival rate and tumor response in the treatment of unresectable HCC still needs to be confirmed ${ }^{[8]}$. Randomized trails or large scale prospective studies evaluating advantages conferred by Y90-TARE treatment in terms of survival or in tumor response are seldom reported. Therefore, this metaanalysis aimed to evaluate the overall survival rate and tumor response in the therapy of Y90-TARE versus c-TACE for unresectable HCC, which might help establishing an optimal therapy for HCC.

Studies were identified using PubMed/Medline, Embase with the following searching terms, \#hepatocellular carcinoma, \#liver cancer, \#hepatic tumor, \#HCC, \#transarterial chemoembolization, \#TACE, \#transarterial radioembolization, \#TARE and \#90Y from December 2008 to January 2017. A manual search of general HCC reviews and references of published clinical trials was performed. Duplicates were found automatically by Endnote (Endnote-EN X7) and deleted manually.

The primary end points were. 3 y overall survival (OR) rate after Y90-TARE or c-TACE treatment, with overall tumor response status as a secondary end point. Reviews without original data, meeting abstracts, expert opinions, case reports, animal experiments, guidelines and single-arm studies were excluded. Studies in languages other than English were excluded too. The reports evaluating 3 y OS rates and tumor response rate comparing Y90-TACE with c-TARE in the unresectable HCC, as well as studies with complete data were included. All data extraction was checked and calculated by two of the coauthors (Qin and Xue). Studies and patients' baseline characteristics were recorded. The quality of all the studies in this meta-analysis was assessed using Newcastle-Ottawa scale $^{[9]}$. Articles with the Newcastle-Ottawa Scale (NOS) exceeding 6 were considered as high quality. All statistical analyses were performed using Review Manage (Revman, version 5.1.0) form the Cochrane Collaboration. The majority of included studies were case control studies. Kaplan-Meier estimates was used to the trails that didn't specifically provide the 3 y OS rate. Dichotomous variables were used to evaluate Odds ratios (OR) and its 95\% confidence interval as the primary measure of treatment effect. Pooled ORs and $95 \%$ CI were performed using either Laird model or Mentel Haenszel model. Q-test and $\mathrm{I}^{2}$ statistics were used to assess the heterogeneity of the included studies. Low level of heterogeneity was defined as $\mathrm{p} \geq 0.1$ and $\mathrm{I}^{2} \leq 50 \%{ }^{[10]}$. The risk of publication bias was assessed by visual inspection of the symmetry of the funnel plot $^{[11]}$. The significance of the pooled ORs was assessed by $\mathrm{X}^{2}$ test. $\mathrm{p}<0.05$ was considered significant.

The study selection process is shown in fig. 1. After duplicate removal, the remaining 187 studies were examined at length. Six case control studies and one cohort study met the inclusion criteria and were

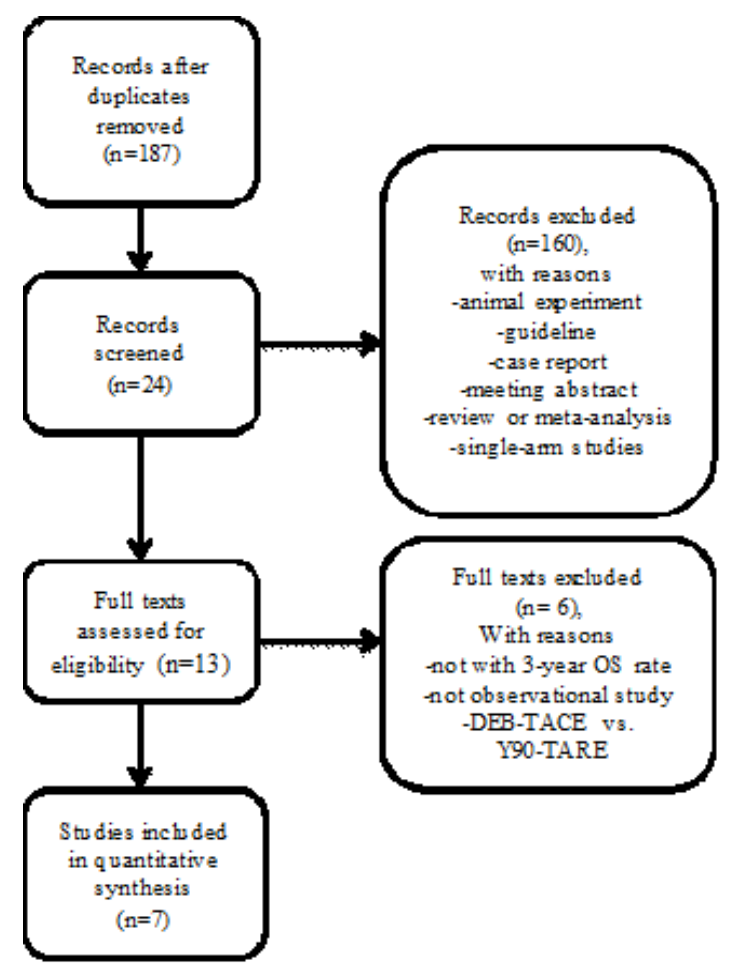

Fig. 1: Flow chart of study selection 
included in the final meta-analysis ${ }^{[4,12-17]}$. A total of 1426 patients were included in this study of which 1013 were treated with c-TACE, 413 with Y90-TARE. Patient characteristics of the included studies were summarized in Table 1. All these studies were published in English. Five studies were conducted in USA, one in China, one each in German and Egypt ${ }^{[12-17]}$. The etiology of the most included patients was a result from HCV or alcohol ${ }^{[4,12-17]}$. Pre-treatment function of most included patients was in Child-Pugh $\mathrm{A}^{[4,12-17]}$. Three studies reported the BCLC stage and more than half of the patients were in BCLC-B stage $e^{[4,14,15]}$.

The quality of all included studies was assessed used the NOS. The scores of 6 case control studies were all 7 and the score of cohort study was 6 . The NOS scores indicated that all of the case control studies were of high quality and the cohort study was of moderate quality (Tables 2 and 3). Four studies directly reported the 3 y OS rates, for the other studies, 3 y OS rates were extracted from Kaplan-Meier curve ${ }^{[4,12-17]}$. Based on the results of tests for heterogeneity between trials $\left(\mathrm{X}^{2}=4.66, \mathrm{P}=0.59, \mathrm{I}^{2}=0 \%\right)$, the Mentel Haenszel model was used to pool the results. The meta-analysis showed that there was no heterogeneity among individual studies and demonstrated that 3 y OS rates in Y90TARE group was significantly higher than in c-TACE group $(\mathrm{OR}=2.03,95 \% \mathrm{CI}=1.45-2.84, \mathrm{p}<0.0001$, fig. 2). The studies included in this meta-analysis used different tumor response rate criteria. Three used Response Evaluation Criteria in Solid Tumors (RECIST) $^{[4,12,13] \text {; one used mRECIST }}{ }^{[16]}$; the others used World Health Organization (WHO) criteria ${ }^{[14,15,17]}$. Overall tumor control was that 7 studies reported the overall tumor control rate. Based on the results of tests for heterogeneity between trials $\left(\mathrm{X}^{2}=31.88, \mathrm{p}<0.0001\right.$, $\mathrm{I}^{2}=81 \%$ ), the Mentel Haenszel model was used to pool the results. The outcome showed that there was severe heterogeneity among individual studies and indicated that the overall tumor control in Y90-TARE group had no significant difference compared to those in c-TACE group $(\mathrm{OR}=1.82,95 \% \mathrm{CI}=0.83-3.99$, $\mathrm{p}=0.14$, fig. 3$)$.

Two randomization-controlled trials from Barcelona and Hong Kong demonstrated a survival benefit for c-TACE compared to the conventional therapy and established c-TACE as the therapeutic standard in intermediate stage $\mathrm{HCC}^{[6,18]}$. c-TACE is the standard of care in the management of intermediate stage unresectable HCC as defined by the BCLC staging system and reinforced by recommendations of AASLD ${ }^{[5,19]}$. With progressive intra-hepatic spread and macrovascular invasion, HCC lesions become less amenable to c-TACE. It has showed that Y90-TARE has superior efficacy than c-TACE ${ }^{[14,20]}$.

TABLE 1: THE BASELINE CHARACTERISTICS OF THE 7 STUDIES

\begin{tabular}{|c|c|c|c|c|c|c|c|c|c|c|c|c|}
\hline Study & Country & $\begin{array}{l}\text { Study } \\
\text { design }\end{array}$ & Treatment & $\mathbf{N}$ & Age & $\begin{array}{c}\text { Gender } \\
\text { M/F }\end{array}$ & HBV \% & HCV \% & Alcohol & $\begin{array}{l}\text { Child } \\
\text {-Pugh } \\
\text { class \% } \\
\text { (A/B) }\end{array}$ & $\begin{array}{c}\text { Pre- } \\
\text { treatment } \\
\text { MELD } \\
\text { score } \\
\end{array}$ & $\begin{array}{c}\text { BCLC } \\
\text { stage } \\
(A / B / C / D)\end{array}$ \\
\hline \multirow[b]{2}{*}{ Carr et al. } & \multirow[b]{2}{*}{ USA } & \multirow{2}{*}{$\begin{array}{l}\text { Cohort } \\
\text { study }\end{array}$} & Y90- & 99 & NA & $70 / 29$ & $9(9)$ & $30(30)$ & 37 (37) & NA & NA & NA \\
\hline & & & c-TACE & 691 & NA & $518 / 173$ & $97(14)$ & $\begin{array}{l}132 \\
(19)\end{array}$ & $217(31)$ & NA & NA & NA \\
\hline \multirow{2}{*}{$\begin{array}{l}\text { El Fouly } \\
\text { et al. }\end{array}$} & \multirow{2}{*}{$\begin{array}{c}\text { Germany } \\
\text { +Egypt }\end{array}$} & \multirow{2}{*}{$\begin{array}{l}\text { Case } \\
\text { control } \\
\text { study }\end{array}$} & Y90-TARE & 44 & $66.1 \pm 8.9$ & $36 / 8$ & $6(14)$ & $8(18)$ & $10(23)$ & $37 / 7$ & $9 \pm 3$ & NA \\
\hline & & & C-TACE & 42 & $58.3 \pm 6.7$ & $38 / 4$ & $1(2)$ & $36(86)$ & NA & $33 / 9$ & $10 \pm 2.5$ & NA \\
\hline \multirow{2}{*}{$\begin{array}{l}\text { Kooby } \\
\text { et al. }\end{array}$} & \multirow[b]{2}{*}{ USA } & \multirow{2}{*}{$\begin{array}{c}\text { Case } \\
\text { control } \\
\text { study }\end{array}$} & Y90-TARE & 27 & $58.7 \pm 10.8$ & $23 / 4$ & NA & $10(37)$ & NA & $13 / 22$ & $10.0 \pm 3.4$ & NA \\
\hline & & & C-TACE & 44 & $61.0 \pm 9.9$ & $36 / 8$ & NA & $25(57)$ & NA & $14 / 22$ & $10.4 \pm 4.2$ & NA \\
\hline \multirow{2}{*}{$\begin{array}{l}\text { Lewando- } \\
\text { wski et al. }\end{array}$} & \multirow{2}{*}{ USA } & \multirow{2}{*}{$\begin{array}{l}\text { Case } \\
\text { control } \\
\text { study }\end{array}$} & Y90-TARE & 43 & $\begin{array}{c}68 \\
(62.8-75)\end{array}$ & $38 / 5$ & $2(5)$ & $14(33)$ & $9(20)$ & $24 / 9$ & NA & $0 / 34 / 9 / 0$ \\
\hline & & & C-TACE & 43 & $\begin{array}{c}65(58.9- \\
67.8)\end{array}$ & $36 / 7$ & $6(14)$ & $16(36)$ & $10(23)$ & $23 / 8$ & NA & $0 / 37 / 4 / 2$ \\
\hline \multirow{2}{*}{$\begin{array}{l}\text { Moreno- } \\
\text { Luna } \\
\text { et al. }\end{array}$} & \multirow[b]{2}{*}{ USA } & \multirow{2}{*}{$\begin{array}{c}\text { Case } \\
\text { control } \\
\text { study }\end{array}$} & Y90-TARE & 61 & $64(29-88)$ & $49 / 12$ & NA & $8(13)$ & $12(20)$ & $53 / 8$ & $9(6-18)$ & 23/13/19 \\
\hline & & & C-TACE & 55 & $66(46-84)$ & $43 / 12$ & NA & 7 (13) & $13(24)$ & $44 / 11$ & $9(6-19)$ & $12 / 34 / 14$ \\
\hline \multirow{2}{*}{$\begin{array}{l}\text { Salem } \\
\text { et al. }\end{array}$} & \multirow{2}{*}{ USA } & \multirow{2}{*}{$\begin{array}{c}\text { Case } \\
\text { control } \\
\text { study }\end{array}$} & Y90-TARE & 123 & $66(30-88)$ & $87 / 36$ & $13(11)$ & $42(35)$ & $20(16)$ & $67 / 54$ & NA & $43 / 65 / 13 / 2$ \\
\hline & & & C-TACE & 122 & $61(33-88)$ & $102 / 20$ & 12 (10) & $56(46)$ & $21(17)$ & $67 / 53$ & NA & $47 / 61 / 12 / 2$ \\
\hline \multirow{2}{*}{$\begin{array}{l}\text { She } \\
\text { et al. }\end{array}$} & \multirow{2}{*}{ China } & \multirow{2}{*}{$\begin{array}{l}\text { Case } \\
\text { control } \\
\text { study }\end{array}$} & Y90-TARE & 16 & $55(37-73)$ & $15 / 1$ & $\begin{array}{c}12 \\
(75.0)\end{array}$ & 0 & NA & $15 / 1$ & $7.5(6-12)$ & NA \\
\hline & & & C-TACE & 16 & $\begin{array}{c}62.5(48- \\
78)\end{array}$ & $13 / 3$ & $\begin{array}{c}13 \\
(81.3)\end{array}$ & $3(27.3)$ & NA & $14 / 2$ & $8.5(6-12)$ & NA \\
\hline
\end{tabular}



STUDIES

\begin{tabular}{|c|c|c|c|c|c|c|c|c|c|c|}
\hline Author & $\begin{array}{l}\text { Is the case } \\
\text { definition } \\
\text { adequate? }\end{array}$ & $\begin{array}{l}\text { Represen- } \\
\text { tativeness } \\
\text { of the case }\end{array}$ & $\begin{array}{c}\text { Selection } \\
\text { of } \\
\text { controls }\end{array}$ & $\begin{array}{c}\text { Definition } \\
\text { of } \\
\text { controls }\end{array}$ & $\begin{array}{l}\text { Main } \\
\text { factor: } \\
\text { Child- } \\
\text { Pugh } \\
\text { class }\end{array}$ & $\begin{array}{l}\text { Secondary } \\
\text { factor: } \\
\text { Aetiology }\end{array}$ & $\begin{array}{l}\text { Ascertain- } \\
\text { ment of } \\
\text { exposure }\end{array}$ & $\begin{array}{c}\text { Same } \\
\text { method } \\
\text { of } \\
\text { ascertain } \\
\text { ment for } \\
\text { cases and } \\
\text { controls }\end{array}$ & $\begin{array}{l}\text { Non- } \\
\text { response } \\
\text { rate }\end{array}$ & $\begin{array}{c}\text { Total } \\
\text { quality } \\
\text { score }\end{array}$ \\
\hline El Fouly et al. & * & * & & * & * & * & & * & * & 7 \\
\hline Kooby et al. & * & * & & * & * & * & & * & * & 7 \\
\hline $\begin{array}{l}\text { Lewandowski } \\
\text { et al. }\end{array}$ & * & * & & * & * & * & & * & * & 7 \\
\hline $\begin{array}{l}\text { Moreno-Luna } \\
\text { et al. }\end{array}$ & * & * & & * & * & * & & * & * & 7 \\
\hline Salem et al. & * & v & & * & * & * & & * & * & 7 \\
\hline She et al. & * & * & & * & * & * & & * & * & 7 \\
\hline
\end{tabular}

TABLE 3: NEWCASTLE-OTTAWA SCALE (NOS) FOR ASSESSING THE QUALITY OF COHORT STUDIES

\begin{tabular}{|c|c|c|c|c|c|c|c|c|c|}
\hline Author & $\begin{array}{l}\text { Represen- } \\
\text { tativeness } \\
\text { of the } \\
\text { exposed } \\
\text { cohort }\end{array}$ & $\begin{array}{l}\text { Selection } \\
\text { of the } \\
\text { non- } \\
\text { exposed } \\
\text { cohort }\end{array}$ & $\begin{array}{l}\text { Ascertain- } \\
\text { ment of } \\
\text { exposure }\end{array}$ & $\begin{array}{l}\text { Demonstration } \\
\text { that outcome } \\
\text { of interest was } \\
\text { not present } \\
\text { at start } \\
\text { of study }\end{array}$ & $\begin{array}{l}\text { Comparability } \\
\text { of cohorts on } \\
\text { the basis of } \\
\text { the design or } \\
\text { analysis }\end{array}$ & $\begin{array}{l}\text { Assessment } \\
\text { of outcome }\end{array}$ & $\begin{array}{l}\text { Was follow } \\
\text {-up long } \\
\text { enough for } \\
\text { outcomes } \\
\text { to occur }\end{array}$ & $\begin{array}{l}\text { Adequacy } \\
\text { of follow } \\
\text { up of } \\
\text { cohorts }\end{array}$ & $\begin{array}{l}\text { Total } \\
\text { quality } \\
\text { score }\end{array}$ \\
\hline$\overline{\text { Carr et }}$ & * & * & & & * & * & * & * & 6 \\
\hline
\end{tabular}

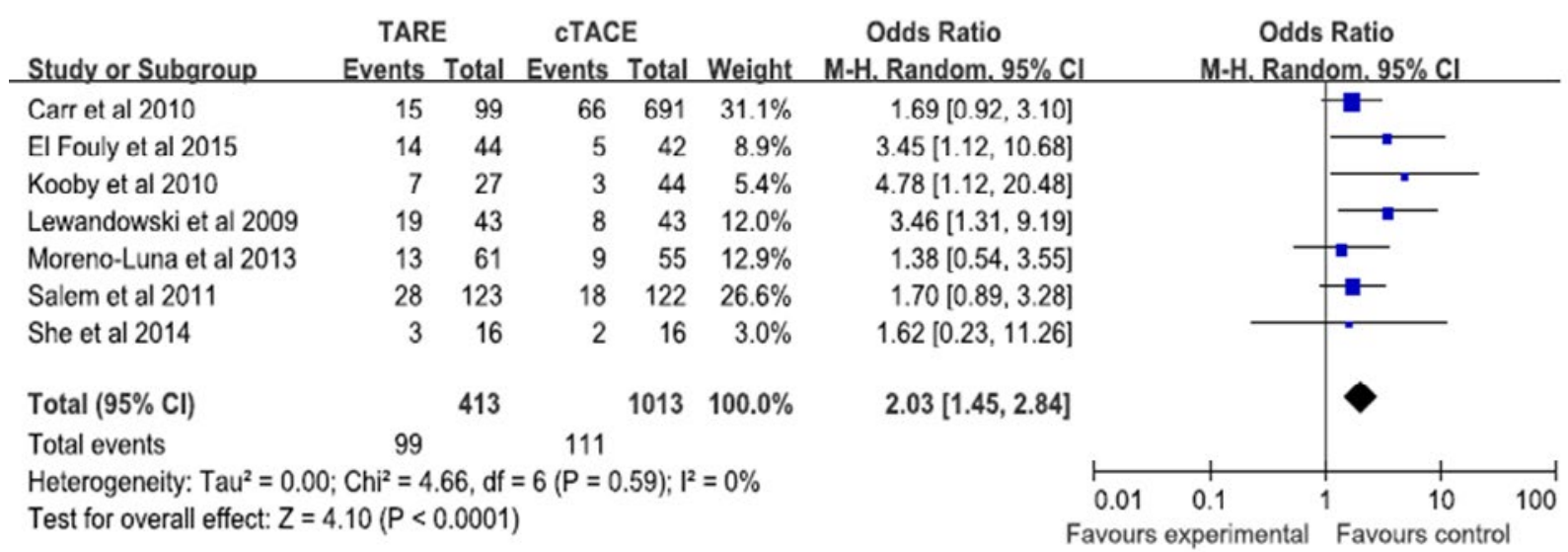

Fig. 2: A meta-analysis of 3 y overall survival rate in hepatocellular carcinoma patients treated with Y90-TARE or c-TACE

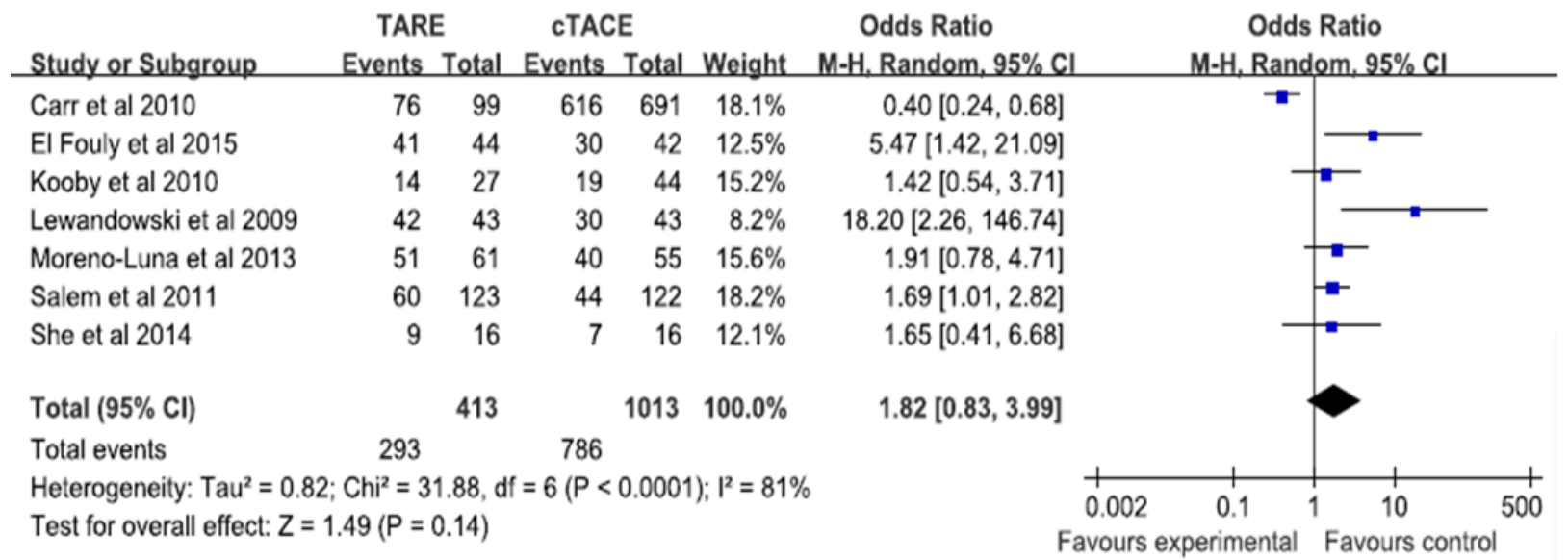

Fig. 3: Forest plots of overall tumor control of all included studies in HCC patients that received Y90-TARE or c-TACE 
www.ijpsonline.com

\begin{tabular}{|c|c|c|c|c|c|c|c|c|c|}
\hline Study or Subgroup & $\begin{array}{l}\text { TARE } \\
\text { Events }\end{array}$ & & $\begin{array}{r}\text { cTAC } \\
\text { Events }\end{array}$ & & Weight & $\begin{array}{l}\text { Odds Ratio } \\
\text { M-H, Random, } 95 \% \mathrm{Cl}\end{array}$ & & $\begin{array}{c}\text { Odds Ratio } \\
\mathrm{M}-\mathrm{H}, \text { Random, } 95 \% \mathrm{Cl}\end{array}$ & \\
\hline Carr et al 2010 & 76 & 99 & 616 & 691 & $0.0 \%$ & $0.40[0.24,0.68]$ & & & \\
\hline El Fouly et al 2015 & 41 & 44 & 30 & 42 & $11.4 \%$ & $5.47[1.42,21.09]$ & & & \\
\hline Kooby et al 2010 & 14 & 27 & 19 & 44 & $18.4 \%$ & $1.42[0.54,3.71]$ & & & \\
\hline Lewandowski et al 2009 & 42 & 43 & 30 & 43 & $5.5 \%$ & $18.20[2.26,146.74]$ & & & \\
\hline Moreno-Luna et al 2013 & 51 & 61 & 40 & 55 & $20.0 \%$ & $1.91[0.78,4.71]$ & & & \\
\hline Salem et al 2011 & 60 & 123 & 44 & 122 & $34.0 \%$ & $1.69[1.01,2.82]$ & & -9 & \\
\hline She et al 2014 & 9 & 16 & 7 & 16 & $10.8 \%$ & $1.65[0.41,6.68]$ & & 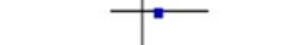 & \\
\hline Total $(95 \% \mathrm{CI})$ & & 413 & & 1013 & $100.0 \%$ & $2.18[1.30,3.64]$ & & & \\
\hline Total events & 293 & & 786 & & & & & & \\
\hline \multirow{2}{*}{\multicolumn{6}{|c|}{$\begin{array}{l}\text { Heterogeneity: } \text { Tau }^{2}=0.14 ; \mathrm{Chi}^{2}=7.61, \mathrm{df}=5(P=0.18) ; I^{2}=34 \% \\
\text { Test for overall effect: } Z=2.95(P=0.003)\end{array}$}} & & 0.002 & 0.1 & 500 \\
\hline & & & & & & & avours & erimental Favours & \\
\hline
\end{tabular}

Fig. 4: Forest plots of overall tumor response in subgroup according to study design, in HCC patients received Y90-TAREor c-TACE

A randomization-controlled study showed a clinical benefit in progression free survival by the treatment of Y90-TARE in patient with liver metastasis to colorectal tumors, after that, Y90-TARE was approved by the FDA ${ }^{[6]}$. However, some other clinical studies had reported conflicting results ${ }^{[4,13,15]}$. The treatment of Y90-TARE in the intermediate stage HCC (BCLC B) has produced median overall survival of $17 \mathrm{mo}$ in multiple reports including the phase II trial. In contrast, c-TACE treatment produced median overall survival ranging from 16 to $22 \mathrm{mo}^{[21]}$. TACE is the transarterial treatment of choice for patients with marginal hepatic reserve (i.e., hyperbilirubinemia, ascites) who may be candidates for transplant. Therefore, it is necessary to compare the efficacy of Y90-TARE with that of c-TACE in intermediate stage HCC.

In this meta-analysis, published studies were evaluated to compare the efficacy of Y90-TARE with that of c-TACE in intermediate stage HCC, which is the most comprehensive study including the 3 y OS rates and tumor response. The outcomes indicated that patients treated with Y90-TARE had significant higher 3 y OS rates; the tumor response had no significant difference between the 2 groups. This study indicated that the $3 \mathrm{y}$ OS rate was significantly higher in Y90-TARE group than in the c-TACE group $(\mathrm{OR}=2.03,95 \% \mathrm{CI}=1.45$, $2.84, \mathrm{p}<0.0001)$, but all the statistical calculation was only based on observational studies and was not be confirmed by randomized clinical trials. Meanwhile since limited patients were included in the current analysis and most of the participators are from USA, more studies with patients of different races are needed to further confirm this conclusion.

For the results of tumor response, meta-analysis of all included studies suggested there was no statistical difference between Y90-TARE group and c-TACE group. Subgroup analysis to pool data according to various design of studies was used. For overall tumor control, the analysis of subgroup demonstrated that Y90-TARE group was superior to c-TACE group (fig. 4). Probably it did not consider the rate at which responses occurred as the Y90-TARE differed from c-TACE. c-TACE responses were observed soon after the first treatment, but Y90-TARE responses occurred much more slowly, for some patients the responses were continued for $>24$ mo after a single treatment ${ }^{[17]}$.

However, some specific limitations of this metaanalysis should be pointed out. First, all the seven included studies were observational studies, 6 of them were case control studies and only one was cohort study. While patients included in the observational studies might have been less selected and might not reflect the true patient population in the real world. Secondly, the etiology of HCC, for example virus hepatitis, alcoholic hepatic disease, was not considered in the analysis. Third, the most patients were from USA, which limited the universality of these conclusions. Hence, updated clinical trials are needed to interpret the results.

\section{Conflict of Interest}

All authors declared that they have no conflict of interest in this work.

\section{REFERENCES}

1. Xing M. $90 \mathrm{Y}$ radioembolization versus chemoembolization in the treatment of hepatocellular carcinoma: an analysis of comparative effectiveness. J Comp Eff Res 2013;2:435-44.

2. Kudo M. Management of hepatocellular carcinoma in Japan: Consensus-based clinical practice guidelines proposed by the Japan Society of Hepatology (JSH) 2010 updated version. Dig Dis 2011;29:339-64.

3. Burrel M. Survival of patients with hepatocellular carcinoma treated by transarterial chemoembolisation (TACE) using drug eluting beads. Implications for clinical practice and trial 
design. J Hepatol 2012;56:1330-35.

4. Moreno-Luna LE. Efficacy and safety of transarterial radioembolization versus chemoembolization in patients with hepatocellular carcinoma. Cardiovasc Intervent Radiol 2013;36:714-23.

5. Bruix JM, Sherman D. American association for the study of liver, management of hepatocellular carcinoma: An update. Hepatol 2011;53:1020.

6. Lo CM. Randomized controlled trial of transarterial lipiodol chemoembolization for unresectable hepatocellular carcinoma. Hepatol 2002;35:1164-71.

7. Lobo L. Unresectable hepatocellular carcinoma: Radioembolization versus chemoembolization: a systematic review and meta-analysis. Cardiovasc Intervent Radiol 2016;39:1580-88.

8. Verslype C. Hepatocellular carcinoma: ESMO-ESDO clinical practice guidelines for diagnosis, treatment and follow-up. Ann Oncol 2012;23:41-8.

9. Wells GA, O'Connell D, Peterson J, Welch V, Losos M, Tugwell P. The Newcastle-Ottawa Scale (NOS) for assessing the quality of nonrandomized studies in meta-analyses. 3rd Symposium on Systematic Reviews: Beyond the Basics 2000;1:3-5.

10. Higgins JP. Measuring inconsistency in meta-analyses. BMJ 2003;327:57-50.

11. Egger M. Bias in meta-analysis detected by a simple, graphical test. BMJ 1997;15:29-64.

12. El Fouly A. In intermediate stage hepatocellular carcinoma: radioembolization with yttrium 90 or chemoembolization? Liver Int 2015;5:27-65.

13. Kooby DA. Comparison of yttrium-90 radioembolization and transcatheter arterial chemoembolization for the treatment of unresectable hepatocellular carcinoma. J Vasc Interv Radiol 2010;21:224-30.

14. Lewandowski RJ. A comparative analysis of transarterial downstaging for hepatocellular carcinoma: chemoembolization versus radioembolization. Am J Transplant 2009;9:920-28.

15. Salem R. Radioembolization results in longer timeto-progression and reduced toxicity compared with chemoembolization in patients with hepatocellular carcinoma. Gastroenterol 2011;140:497-507.

16. She WH. Survival analysis of transarterial radioembolization with yttrium-90 for hepatocellular carcinoma patients with HBV infection. Hepatobiliary Surg Nutr 2014;3:185-93.

17. Carr BI. Therapeutic equivalence in survival for hepatic arterial chemoembolization and yttrium 90 microsphere treatments in unresectable hepatocellular carcinoma: A two-cohort study. Cancer 2010;116:1305-14.

18. Llovet JM. Arterial embolisation or chemoembolisation versus symptomatic treatment in patients with unresectable hepatocellular carcinoma: a randomised controlled trial. Lancet 2002;359:1734-39.

19. Lencioni R, Crocetti L. Local-regional treatment of hepatocellular carcinoma. Radiol 2012;262:43-58.

20. Akinwande $\mathrm{O}$. Radioembolization versus chemoembolization (DEBDOX) for the treatment of unresectable hepatocellular carcinoma: A propensity matched study. Anticancer Res 2016;36:239-46.

21. Mazzaferro V. Yttrium-90 radioembolization for intermediateadvanced hepatocellular carcinoma: A phase 2 study. Hepatol 2013;57:1826-37.

This is an open access article distributed under the terms of the Creative Commons Attribution-NonCommercial-ShareAlike 3.0 License, which allows others to remix, tweak, and build upon the work non-commercially, as long as the author is credited and the new creations are licensed under the identical terms

This article was originally published in a special issue, "Biomedical research applications in Pharmaceutical Sciences" Indian J Pharm Sci 2020:82(2)Spl issue3;76-81 